Original Research Paper

\title{
Phytochemical Screening of Decoction and Ethanolic Extract of Amomum dealbatum Roxb. Leaves
}

\author{
Nisa Isneni Hanifa ${ }^{1 *}$, Dyke Gita Wirasisya ${ }^{1}$, Arinda Eka Muliani ${ }^{1}$, Septia Budi Utami ${ }^{1}$, \\ Anggit Listyacahyani Sunarwidhi ${ }^{1}$ \\ ${ }^{1}$ Program Studi Farmasi, Fakultas Kedokteran, Universitas Mataram, Mataram, Indonesia
}

\author{
Article History \\ Received : June $15^{\text {th }}, 2021$ \\ Revised : June $28^{\text {th }}, 2021$ \\ Accepted : July 03 ${ }^{\text {th }}, 2021$ \\ Published : July 06 ${ }^{\text {th }}, 2021$ \\ *Corresponding Author: \\ Nisa Isneni Hanifa, \\ Program Studi Farmasi, \\ Fakultas Kedokteran, \\ Universitas Mataram, Mataram, \\ Indonesia; \\ Email: \\ nisa.isneni.hanifa@unram.ac.id
}

\begin{abstract}
Renggak (Amomum dealbatum Roxb.) is a species from the genus Amomum widely spread in Lombok. Traditionally, Amomum dealbatum Roxb. (renggak) is an antiseptic to treat rheumatism and arthritis. However, there was limited report of its phytochemical contents and biological activity of Amomum dealbatum Roxb. This study is preliminary research that aims to determine the phytochemical content of Amomum dealbatum Roxb. leaf decoction and its ethanolic extract. For this study, we used two different extraction methods. The fully powdered plant used for the successive extraction in the cold process for maceration methods was $800 \mathrm{~g}$, and ethanols were used as solvents. We used a traditional receipt that utilized three fresh leaves in the decoction methods with 4,5 L of water as solvents. Phytochemical screening was carried out qualitatively by using the tube method with specific reagents for each compound. Important phytochemicals that were screened are flavonoids, alkaloids, tannins, saponins, steroids, and triterpenoids. Phytochemical screening from plant extract and decoction revealed the presence of flavonoids, alkaloids, and tannins. Triterpenoid was only detected on the extract, and none of the extract and decoction have saponins and steroids. Our finding provides information about secondary metabolites that present in Amomum dealbatum Roxb. These phytochemical findings are essential and might be useful as quality parameters and to predicts its biological activities.
\end{abstract}

Keywords: Amomum dealbatum Roxb. leaves; decoction; extract; Phytochemical screening.

\section{Pendahuluan}

Famili Zingiberaceae merupakan famili yang memiliki banyak spesies yang digunakan sebagai obat tradisional. Zingiberaceae memiliki beberapa genus, diantaranya Alpinia, Amomum, Boesenberigia, Curcuma, Etlingera, Kaempferia, dan Zingiber. Famili Zingiberaceae memiliki lebih dari 1.200 spesies yang tersebar di hutan tropis Asia tenggara. Amomum dealbatum Roxb. atau yang umum dikenal sebagai renggak merupakan salah satu spesies dalam famili ini (Sarangnga et al., 2013).

Studi etnomedisin penggunaan renggak (Amomum dealbatum Roxb.) sebagai obat tradisional telah banyak dilaporkan, terutama di daerah Asia (Dalisay et al., 2018; Pancharoen et al., 2000; Rahman, 2010; Tushar et al., 2010). Tushar et al. (2010) menjelaskan penggunaan tradisional renggak di India, diantaranya bagian rimpang untuk mengobati nyeri sendi dan abses, jus daun sebagai antiseptik, dan serbuk biji untuk mengatasi rematik otot. Khisha et al. (2012) melaporkan penggunaan ekstrak rimpang renggak oleh masyarakat Bangladesh untuk mengobati abses. Masyarakat Filipina menggunakan rebusan rimpang renggak untuk mengatasi batuk dan buah renggak untuk mengobati diare (Dalisay et al., 2018). Di Indonesia, rebusan rimpang renggak digunakan oleh wanita pascasalin untuk membersihkan daerah kewanitaan (Pancharoen et al., 2000), sedangkan di daerah Narmada, Lombok Barat, rebusan bagian daun dari tanaman renggak 
digunakan sebagai air mandi wanita pascasalin. Rebusan ini dianggap dapat menghilangkan bau darah nifas.

Hingga saat ini, penelitian eksplorasi aktivitas biologis dan kandungan senyawa aktif pada tanaman Amomum dealbatum Roxb. terbatas pada bagian buah dan rimpang saja. Ekstrak etanol buah renggak dilaporkan memiliki aktivitas antifungi terhadap Pyricularia oryzae dan sebagai antibakteri terhadap Xanthomonas oryzae. Ekstrak tersebut dilaporkan positif mengandung beberapa metabolit sekunder antara lain flavonoid, terpenoid, alkaloid, steroid, dan saponin (Nufus, 2020). Adapun ekstrak rimpang renggak dilaporkan mengandung senyawa flavonoid dan terpenoid (Rachkeeree et al., 2020). Penelitian terkait bagian lain dari tanaman renggak belum dilaporkan.

Bagian daun Amomum dealbatum Roxb. memiliki ketersediaan yang melimpah. Bagian ini juga potensial mengandung senyawa aktif berkhasiat karena semua bagian tumbuhan renggak memiliki bau khas yang memungkinkan adanya kandungan minyak atsiri (Yurleni, 2018). Belum adanya penelitian mengenai kandungan metabolit sekunder pada daun renggak menjadi landasan pentingnya dilakukan penelitian tentang skrining fitokimia daun Amomum dealbatum Roxb. Pada penelitian ini akan membandingkan kandungan metabolit sekunder pada sampel dengan metode ekstraksi yang berbeda yaitu maserasi dengan pelarut etanol dan rebusan yang dipergunakan pada penggunaan tradisional.

\section{Bahan dan Metode}

\section{Bahan dan Alat}

Bahan yang digunakan pada penelitian ini adalah daun renggak (Amomum dealbatum Roxb, aquades, etanol 96\% (Merck), aluminium foil (Klin pak®), amilalkohol p.a. (Merck), asam asetat anhidrat p.a. (Merck), $\mathrm{FeCl}_{3} 1 \%$ teknis (Merck), kertas saring Whatman no. 1 (Whatman), $\mathrm{HCl}$ pekat p.a. (Merck), $\mathrm{H}_{2} \mathrm{SO}_{4}$ pekat p.a. (Merck), kloroform p.a. (Merck), serbuk Mg p.a. (Merck), reagen Dragendorff p.a. (Nitra Kimia), reagen Mayer p.a. (Nitra Kimia), dan reagen Wagner p.a. (Nitra Kimia).

Alat yang digunakan yaitu alat-alat gelas (Iwaki $\left.{ }^{\circledR}\right)$, freeze dryer (Christ $\left.{ }^{\circledR}\right)$, hotplate (Labnet $\AA$ ), mikropipet (Labnet $\AA)$, panci, pengaduk kayu, pisau, rak tabung reaksi, sendok besi, timbangan analitik (Kern®), tip (Onemed $\left.{ }^{\circledR}\right)$, ultralow temperature freezer (Thermo Fisher Scientific $\AA$ ), kompor listrik, thermometer, dan vortex (Labnet $\left.{ }^{\circledR}\right)$.

\section{Pengambilan, Determinasi, dan Preparasi Simplisia Daun Renggak}

Sampel daun renggak dikoleksi dari Desa Pemepek, Kecamatan Pringgarata, Kabupaten Lombok Tengah, Provinsi NTB. Daun renggak yang dipanen merupakan daun tua yang terbuka sempurna dan pada saat tanaman sedang tidak berbunga. Tanaman renggak dideterminasi di laboratorium Program Studi Biologi Fakultas MIPA Universitas Mataram untuk mengetahui klasifikasi tanaman yang digunakan.

Sampel daun renggak mula-mula dilakukan sortasi basah, dicuci menggunakan air bersih sebanyak 3 kali, ditiriskan dan dilakukan pengeringan dengan cara dijemur pada tempat teduh. Setelah kering, dilakukan sortasi kering kemudian dihaluskan menjadi serbuk kasar menggunakan blender dan disimpan dalam wadah tertutup.

\section{Pembuatan Rebusan dan Ekstrak Daun Renggak}

Rebusan daun renggak dibuat berdasarkan metode empiris masyarakat Narmada, Lombok Barat. Kemudian, tiga helai daun renggak segar dicuci bersih pada air mengalir. Daun ditimbang kemudian dirajang menjadi bagian yang lebih kecil. Daun direbus dengan menggunakan 4,5 L air bersih hingga mendidih. Hasil rebusan disaring untuk mendapatkan filtrat dan dimasukkan dalam wadah yang sesuai. Filtrat rebusan daun renggak selanjutnya digunakan untuk skrining fitokimia dan sisanya dimasukkan ke dalam freezer dengan suhu $-80^{\circ} \mathrm{C}$ selama 24 jam. Sampel rebusan yang telah dibekukan diliofilisasi menggunakan freeze dryer untuk mereduksi kadar airnya.

Sebanyak $800 \mathrm{~g}$ serbuk kasar daun renggak (Amomum dealbatum Roxb.) diekstraksi menggunakan metode maserasi. Serbuk daun renggak direndam dengan pelarut etanol $96 \%$ dengan perbandingan 1:10 kemudian dilakukan penyarian selama 1 kali 24 jam sambil diaduk berkala. Sampel disaring untuk memisahkan maserat dan ampas. Dilakukan remaserasi sebanyak dua kali dengan menggunakan pelarut 
dan perbandingan yang sama. Maserat yang diperoleh kemudian dikumpulkan dan dilakukan pemekatan menggunakan waterbath sederhana dengan suhu di bawah $50^{\circ} \mathrm{C}$ hingga diperoleh ekstrak kental.

\section{Karakterisasi Rebusan dan Ekstrak Daun Renggak}

Rebusan dan ekstrak etanol daun renggak ditetapkan karakteristik fisik meliputi bentuk dan warna (Direktorat Pengawasan Obat Tradisional, 2000), serta dilakukan penapisan fitokimia untuk mengetahui kandungan senyawa metabolit sekunder pada sampel.

\section{Uji flavonoid}

Sebanyak $0,1 \mathrm{~g}$ ekstrak dilarutkan dengan $10 \mathrm{~mL}$ aquades panas kemudian dipanaskan selama 5 menit, didinginkan dan disaring. Filtrat (atau sampel rebusan) sebanyak $5 \mathrm{~mL}$ diambil lalu ditambahkan $0,1 \mathrm{~g}$ serbuk $\mathrm{Mg}, 1 \mathrm{~mL} \mathrm{HCl}$ pekat dan $1 \mathrm{~mL}$ amilalkohol. Hasil positif ditandai dengan terbentuknya warna kuning, jingga atau merah (Nugrahani et al., 2016).

\section{Uji alkaloid}

Sebanyak 0,1 g ekstrak dilarutkan dalam 9 $\mathrm{mL}$ aquades panas (9 $\mathrm{mL}$ sampel rebusan) dan ditambahkan $1 \mathrm{~mL} \mathrm{HCl} \mathrm{2N}$. Larutan dipanaskan selama 2 menit, didinginkan dan disaring. Filtrat dibagi kedalam 3 tabung reaksi, masing-masing 2 $\mathrm{mL}$. Tiap tabung ditambahkan dengan masingmasing pereaksi. Pada penambahan pereaksi Mayer, positif mengandung alkaloid jika terbentuk endapan putih atau kuning. Pada penambahan pereaksi Wagner dan Dragendorff, positif mengandung alkaloid jika terbentuk endapan cokelat kemerahan (Malik et al., 2014; Muthmainnah, 2017).

\section{Uji tanin}

Sebanyak 0,1 g ekstrak dilarutkan dengan $10 \mathrm{~mL}$ aquades panas kemudian dipanaskan selama 5 menit, didinginkan dan disaring. Filtrat (atau sampel rebusan) sebanyak $5 \mathrm{~mL}$ diambil dan tambahkan $\mathrm{FeCl} 3$ 1\%. Hasil positif ditandai dengan terbentuknya warna hijau kehitaman (Nugrahani et al., 2016).

\section{Uji saponin}

Sebanyak 0,1 g ekstrak dilarutkan dengan $10 \mathrm{~mL}$ aquades panas kemudian dididihkan selama 5 menit dan disaring. Filtrat (atau sampel rebusan sebanyak $5 \mathrm{~mL}$ ) yang diperoleh dimasukkan kedalam tabung reaksi lalu dikocok selama 10 detik, didiamkan selama 10 menit dan ditambahkan 1 tetes $\mathrm{HCl} 2 \mathrm{~N}$. Hasil positif saponin ditandai dengan terbentuknya busa yang stabil setelah didiamkan selama 10 menit dan ditambahkan HCl 2N (Nugrahani et al., 2016).

\section{Uji steroid dan triterpenoid}

Sebanyak $0,1 \mathrm{~g}$ ekstrak dilarutkan dengan $5 \mathrm{~mL}$ aquades panas dan disaring. Filtratnya (sebanyak $5 \mathrm{~mL}$ sampel rebusan) dimasukkan ke dalam corong pisah kemudian ditambahkan $5 \mathrm{~mL}$ kloroform. Dilakukan partisi cair-cair dengan menggunakan corong pisah. Lapisan kloroform ditampung dan ditambahkan $1 \mathrm{~mL}$ asam asetat anhidrat kemudian ditetesi asam sulfat pekat sebanyak 2 tetes melalui dinding tabung. Jika terbentuk warna hijau kebiruan menunjukkan adanya steroid. Jika adanya cincin merah kecokelatan pada perbatasan dua pelarut menunjukkan adanya triterpenoid (Simaremare, 2014).

\section{Hasil dan Pembahasan}

\section{Pengumpulan, Determinasi, dan Preparasi} Simplisia Daun Renggak

Tanaman renggak yang digunakan adalah tanaman non-budidaya yang terdapat di Desa Pemepek, Pringgarata, Lombok Tengah. Kriteria daun renggak yang dipanen yaitu daun tua dari tanaman dewasa, belum berbunga, dan sehat, serta daun yang terbuka sempurna. Kriteria ini sesuai dengan pedoman panen daun menurut Badan Litbang Kesehatan (2011) yang perlu memperhatikan waktu panen, bahan yang akan dipanen, dan teknik panen karena berkaitan dengan kandungan senyawa aktif yang ada di dalam tanaman.

Hasil determinasi sampel menggunakan bagian akar, batang, daun dan buah tanaman menunjukkan bahwa tanaman yang digunakan adalah Amomum dealbatum Roxb. Proses determinasi menjadi hal krusial pada sebuah penelitian untuk memastikan kebenaran identitas spesies yang digunakan sebagai sampel (Pangestuty, 2016).

Daun renggak segar diproses menjadi simplisia dengan metode kering angin. Pengeringan bahan bertujuan untuk mengurangi 
kadar air pada sampel yang dapat menjadi media pertumbuhan mikroorganisme sehingga lebih awet dalam penyimpanan. Selain itu, pengeringan dapat menghentikan reaksi enzimatik pada tanaman yang dapat mengurai senyawa aktif sehingga mengurangi mutu simplisia (Widaryanto \& Azizah, 2018). Metode pengeringan ini dipilih untuk menghindari rusaknya senyawa aktif dalam tanaman akibat paparan sinar matahari secara langsung (Widarta \& Wiadnyani, 2019). Simplisia daun renggak yang diperoleh pada penelitian ini sebanyak 800 g.

\section{Pembuatan Rebusan dan Ekstrak Daun Renggak}

Rebusan daun renggak dibuat dengan merebus 3 helai daun dengan bobot $95 \mathrm{~g}$ yang telah dirajang dengan ukuran seragam dalam 4,5 L air bersih hingga mendidih. Proses perebusan ini didasarkan pada penggunaan empiris rebusan daun renggak di masyarakat Narmada yang digunakan sebagai air untuk mandi wanita pascamelahirkan (Tushar et al., 2010). Filtrat rebusan daun renggak dilakukan skrining fitokimia kemudian diliofilisasi untuk mereduksi air dalam rebusan sehingga diperoleh hasil akhir berupa serbuk yang lebih stabil dalam penyimpanan (Haseley \& Oetjen, 2018). Bobot serbuk hasil liofilisasi sebanyak 2,99 g dengan rendemen yang diperoleh sebesar 3,15\%.

Pembuatan ekstrak daun renggak menggunakan metode maserasi dengan pelarut etanol 96\%. Pemilihan pelarut ini berdasarkan kemampuan etanol 96\% untuk mengekstrak senyawa organik yang bersifat polar maupun non polar sehingga hampir semua senyawa metabolit sekunder dapat terekstraksi (Noviyanti, 2016). Komposisi simplisia dan pelarut sebesar 1:10 digunakan dengan tujuan untuk memperoleh jumlah senyawa aktif dengan maksimal. Hal ini disebabkan oleh penggunaan pelarut dengan jumlah optimal akan menyebabkan pemecahan dinding dan membran sel akibat adanya perbedaan tekanan di dalam dan luar sel, sehingga senyawa aktif akan terlarut dalam pelarut (Yulianingtyas \& Kusmartono, 2016).

Metode maserasi digunakan karena metode ini cukup sederhana, mudah dilakukan, dan jumlah pelarut yang digunakan lebih sedikit (Bruneton, 1999). Ekstrak kental yang diperoleh setelah penguapan sebesar 31,459 g dengan rendemen sebanyak $3,9 \%$.

\section{Karakterisasi Rebusan dan Ekstrak Daun Renggak}

Hasil karakterisasi fisik terhadap rebusan dan ekstrak daun renggak meliputi bentuk dan warna, serta penapisan fitokimia untuk mengetahui kandungan senyawa metabolit sekunder berupa flavonoid, alkaloid, tanin, saponin, steroid, dan triterpenoid disajikan pada tabel 1. Analisis kualitatif fitokimia menggunakan metode tabung dengan melihat adanya endapan pada uji alkaloid, perubahan warna pada uji flavonoid, tanin, steroid, dan triterpenoid, serta pembentukan busa pada uji saponin (Gambar 1).

Tabel 1. Hasil karakterisasi fisik dan penapisan fitokimia rebusan dan ekstrak daun renggak

\begin{tabular}{|c|c|c|c|c|c|c|c|c|}
\hline \multirow{2}{*}{ Sampel } & \multirow{2}{*}{ Bentuk } & \multirow{2}{*}{ Warna } & \multicolumn{6}{|c|}{ Penapisan Fitokimia } \\
\hline & & & Flavonoid & Alkaloid & Tanin & Saponin & Steroid & Triterpenoid \\
\hline Rebusan & Cair & $\begin{array}{l}\text { Coklat } \\
\text { muda }\end{array}$ & + & + & + & - & - & - \\
\hline $\begin{array}{l}\text { Ekstrak } \\
\text { etanolik }\end{array}$ & $\begin{array}{c}\text { Ekstrak } \\
\text { Kental }\end{array}$ & $\begin{array}{c}\text { Coklat } \\
\text { tua }\end{array}$ & + & + & + & - & - & + \\
\hline Keterangan: & $\begin{array}{l}+ \text { : sampel } \\
\text { - : sampel }\end{array}$ & $\begin{array}{l}\text { igandung } \\
\text { k mengal }\end{array}$ & $\begin{array}{l}\text { senyawa ters } \\
\text { dung senyaw }\end{array}$ & $\begin{array}{l}\text { but } \\
\text { tersebut }\end{array}$ & & & & \\
\hline
\end{tabular}




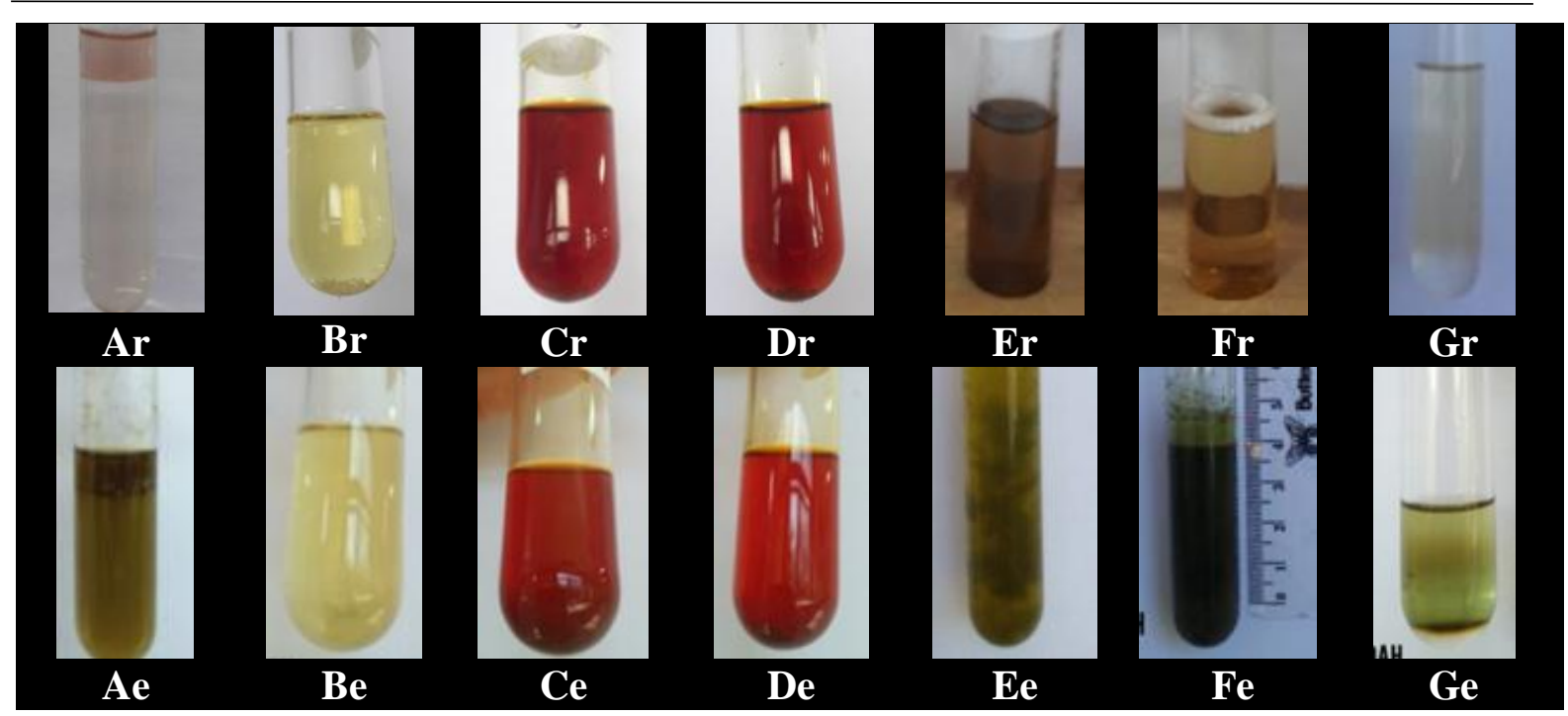

Gambar 1. Hasil penapisan fitokimia daun renggak (Amomum dealbatum $\mathrm{Roxb}$.) (A = flavonoid, $\mathrm{B}=$ alkaloid-Mayer, $\mathrm{C}=$ alkaloid-Wagner, $\mathrm{D}=$ alkaloid-Dragendorff, $\mathrm{E}=\operatorname{tanin}, \mathrm{F}=$ saponin, $\mathrm{G}=$ steroid dan triterpenoid, $\mathrm{r}=$ rebusan, $\mathrm{e}=$ ekstrak)

\section{Flavonoid}

Uji flavonoid pada kedua sampel menggunakan metode Shinoda test. Hasil analisis senyawa flavonoid pada kedua sampel menunjukkan bahwa rebusan dan ekstrak etanolik daun renggak mengandung senyawa flavonoid yang ditunjukkan dengan perubahan warna berturut-turut menjadi jingga dan kuning (Gambar 1. Ar dan Ae). Penelitian oleh Nufus (2020) menunjukkan bahwa ekstrak etanolik buah renggak (Amomum dealbatum Roxb.) mengandung senyawa flavonoid. Hasil penapisan flavonoid pada ekstrak etanol, etil asetat, dan heksan rimpang A. dealbatum menunjukkan bahwa ekstrak etanol dan etil asetat mengandung senyawa flavonoid, sedangkan ekstrak heksan tidak (Rachkeeree et al., 2020). Namun belum ada penelitian yang mengkaji bagian daun dari tanaman A. dealbatum.

Reaksi yang terjadi pada campuran sampel dengan pereaksi Shinoda dapat dilihat pada gambar 2. Penambahan $\mathrm{HCl}$ pekat pada larutan sampel bertujuan untuk menghidrolisis glikosida flavonoid yang umumnya terdapat dalam tanaman sehingga menjadi aglikon flavonoid. Dalam suasana asam, $\mathrm{Mg}$ bereaksi dengan $\mathrm{HCl}$ membentuk ion $\mathrm{Mg}^{2+}$ dan gas $\mathrm{H}_{2}$. Terbentuknya gas hidrogen terlihat dari adanya gelembung pada campuran. Ion $\mathrm{Mg}^{2+}$ akan berikatan dengan flavonoid menghasilkan senyawa kompleks dan menimbulkan perubahan warna menjadi kuning, jingga ataupun merah (Nugrahani et al., 2016).

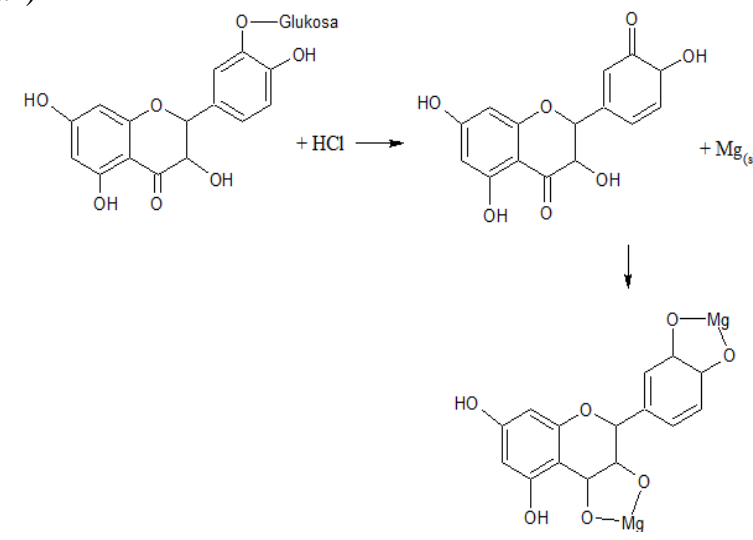

Gambar 2. Reaksi flavonoid dengan pereaksi Shinoda (Nugrahani et al., 2016)

\section{Alkaloid}

Hasil uji alkaloid rebusan dan ekstrak daun renggak menunjukkan bahwa kedua sampel ini mengandung senyawa alkaloid. Hal ini ditunjukkan oleh terbentuknya endapan putih pada pereaksi Mayer dan endapan cokelat kemerahan pada pereaksi Wagner dan Dragendorff (Gambar 1. Br, $\mathrm{Cr}$, Dr, Be, Ce, dan De). Suatu sampel dapat dikatakan mengandung alkaloid jika paling sedikit 2 dari 3 pereaksi menunjukkan hasil positif (Meigaria et al., 2016). Ekstrak etanol buah renggak diketahui mengandung senyawa alkaloid (Nufus, 2020), sedangkan ekstrak etanol, etil asetat, dan heksan rimpang renggak tidak mengandung alkaloid (Rachkeeree et al., 2020).

Penambahan $\mathrm{HCl} 2 \mathrm{M}$ pada sampel bertujuan untuk mengekstraksi senyawa alkaloid. Hal ini karena alkaloid bersifat basa, sehingga penambahan $\mathrm{HCl}$ menyebabkan terbentuknya garam alkaloid. 
Garam alkaloid ini kemudian diendapkan dengan penambahan reagen, yaitu Mayer, Dragendorff, dan Wagner. Endapan yang terbentuk merupakan hasil reaksi ion $\mathrm{K}^{+}$dari reagen yang berikatan dengan atom $\mathrm{N}$ pada alkaloid membentuk kompleks kalium-alkaloid (Muthmainnah, 2017).

Atom nitrogen pada alkaloid memiliki pasangan elektron bebas yang dapat membentuk ikatan kovalen koordinat dengan ion $\mathrm{K}^{+}$dari kalium tetraiodomerkurat (II) pada pereaksi Mayer membentuk endapan putih kekuningan (Gambar 3a). Endapan cokelat kemerahan pada pereaksi Wagner terbentuk karena ion $\mathrm{K}^{+}$pada kalium iodida akan membentuk ikatan kovalen koordinat dengan nitrogen pada alkaloid sehingga membentuk kompleks kalium-alkaloid yang mengendap. Warna yang timbul pada endapan terjadi karena iodin $\left(\mathrm{I}_{2}\right)$ bereaksi dengan ion $\mathrm{I}^{-}$dari kalium iodida menghasilkan ion $\mathrm{I}_{3}^{-}$yang berwarna cokelat kemerahan (Gambar 3b). Endapan cokelat kemerahan pada pereaksi Dragendorff terbentuk karena nitrogen pada alkaloid membentuk ikatan kovalen dengan ion $\mathrm{K}^{+}$dari kalium tetraiodobismutat membentuk endapan kaliumalkaloid yang berwarna cokelat kemerahan (Gambar 3c) (Marliana et al., 2005).

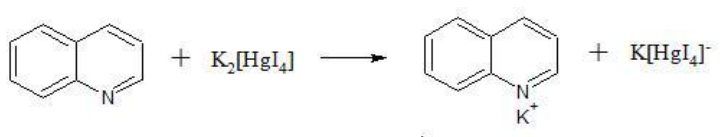

$\mathbf{a}$ Endapan putih kekuningan

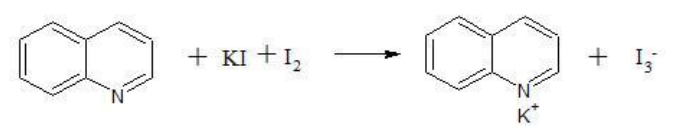

b $\downarrow$ Endapan cokelat kemerahan

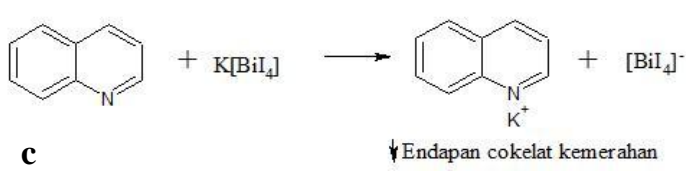

Gambar 3. Reaksi identifikasi alkaloid oleh reagen (a) Mayer, (b) Wagner, dan (c) Dragendorff (Marliana et al., 2005)

\section{Tanin}

Pada uji tanin, kedua sampel direaksikan dengan $\mathrm{FeCl}_{3}$ dan menghasilkan warna hijau kehitaman (Gambar 1. Er dan Ee) yang menunjukkan bahwa sampel ini positif mengandung senyawa tanin. Senyawa tanin di dalam sampel akan berikatan dengan $\mathrm{Fe}^{3+}$ membentuk kompleks yang menyebabkan perubahan warna menjadi hijau kehitaman atau biru kehitaman tergantung dari jenis senyawa tanin (Ergina et al., 2014). Ekstrak etanol, etil asetat, dan heksan bagian rimpang renggak tidak mengandung senyawa tanin (Rachkeeree et al., 2020). Reaksi perubahan warna yang terjadi pada identifikasi senyawa tanin dapat dilihat pada gambar 4 .

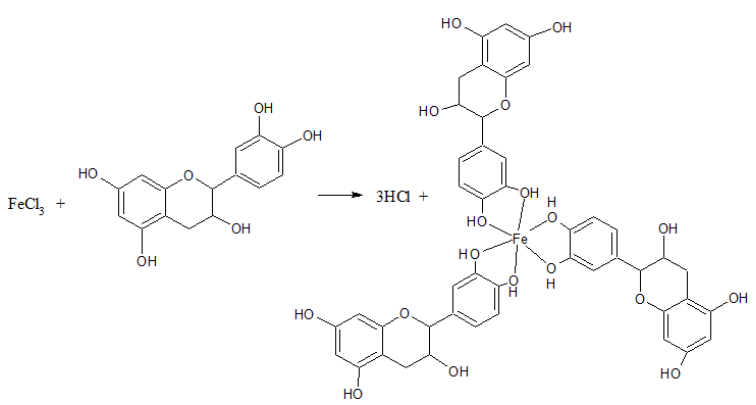

Gambar 4. Reaksi identifikasi senyawa tanin (Ergina et al., 2014)

\section{Saponin}

Pada uji saponin, kedua sampel ini terlihat memiliki busa dengan tinggi kurang dari $1 \mathrm{~cm}$ setelah ditambahkan $\mathrm{HCl} 2 \mathrm{~N}$ (Gambar 1. Fr dan Fe). Hal ini menunjukkan bahwa rebusan dan ekstrak daun renggak tidak mengandung senyawa saponin. Ekstrak etanol, etil asetat, dan heksan rimpang renggak juga tidak mengandung saponin (Rachkeeree et al., 2020), namun ekstrak etanol buah renggak menunjukkan hasil positif uji saponin (Nufus, 2020).

Uji saponin menggunakan metode frothing test, dimana larutan sampel dikocok selama 1 menit dan diamati busa yang terbentuk. Apabila terbentuk busa yang stabil dengan tinggi lebih dari $1 \mathrm{~cm}$ setelah penambahan $\mathrm{HCl} 2 \mathrm{~N}$ maka sampel dikatakan positif mengandung saponin (Nugrahani et al., 2016). Pembentukan busa disebabkan oleh struktur senyawa saponin berupa glikosida yang memiliki senyawa sapogenin nonpolar dan rantai samping polar yang larut dalam air. Pada saat dikocok dengan air, saponin dapat membentuk misel karena adanya gugus polar dan non polar yang bersifat aktif permukaan. Gugus polar akan menghadap keluar sedangkan gugus non polar akan menghadap kedalam. Kondisi inilah yang tampak seperti busa (Sangi et al., 2008). Reaksi hidrolisis saponin dalam air dapat dilihat pada Gambar 5. 


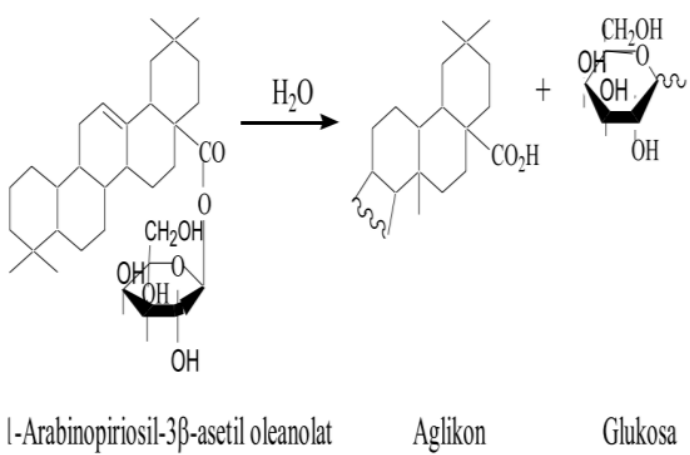

Gambar 5. Reaksi hidrolisis saponin dalam air (Marliana et al., 2005)

\section{Steroid dan Triterpenoid}

Steroid dan triterpenoid dapat dideteksi dengan penambahan pereaksi LiebermannBurchard. Rebusan dan larutan ekstrak daun renggak dipartisi cair-cair menggunakan kloroform untuk memisahkan senyawa berdasarkan kepolarannya. Senyawa yang bersifat polar akan mudah larut pada air, sedangkan senyawa yang bersifat non polar akan mudah larut pada kloroform. Menurut Widiyati (2006), steroid dan triterpenoid dapat larut dalam pelarut non polar seperti kloroform atau karbon tetraklorida. Deteksi senyawa steroid dan triterpenoid menggunakan reagen asam asetat anhidrat dan $\mathrm{H}_{2} \mathrm{SO}_{4}$ pekat. Positif adanya steroid ditandai dengan terbentuknya warna hijau kebiruan, sedangkan positif triterpenoid ditandai dengan terbentuknya cincin merah kecokelatan diantara kedua lapisan (Simaremare, 2014).

Asam asetat anhidrat bereaksi dengan asam sulfat pekat membentuk karbokation, dimana karbokation ini akan bereaksi dengan atom O pada gugus $\mathrm{OH}$ senyawa triterpenoid. Reaksi ini menyebabkan terjadinya perubahan warna menjadi merah kecokelatan. Penambahan asam sulfat pekat menyebabkan dehidrasi pada senyawa steroid. Selanjutnya terjadi reaksi oksidasi melalui pembentukan ikatan rangkap terkonjugasi sehingga terbentuk warna hijau kebiruan (Sholikhah, 2016).

Hasil pengujian rebusan daun renggak dengan pereaksi Liebermann-Burchard tidak menunjukkan perubahan warna (Gambar 1. Gr). Hal ini menunjukkan bahwa rebusan daun renggak tidak mengandung senyawa steroid dan triterpenoid. Hal ini disebabkan karena proses ekstraksi senyawa metabolit sekunder menggunakan air yang bersifat polar, sehingga tidak mampu mengekstrak senyawa steroid dan triterpenoid yang bersifat non polar. Proses ekstraksi memiliki prinsip like dissolve like, yaitu senyawa polar akan larut dalam pelarut polar, begitupun sebaliknya (Prasasty et al., 2019).

Hasil uji sampel ekstrak etanolik daun renggak dengan pereaksi Liebermann-Burchard menunjukkan adanya pembentukan cincin merah kecokelatan pada batas 2 pelarut (Gambar 1. Ge). Hal ini menandakan bahwa ekstrak etanolik daun renggak positif mengandung senyawa triterpenoid, namun tidak mengandung senyawa steroid. Adanya kandungan senyawa triterpenoid pada sampel ekstrak daun renggak karena penggunaan pelarut etanol $96 \%$ pada ekstraksi, dimana etanol merupakan pelarut universal yang mampu mengekstrak senyawa polar maupun non polar (Noviyanti, 2016).

Penelitian oleh Nufus (2020) menunjukkan bahwa ekstrak etanol buah renggak mengandung senyawa steroid dan terpenoid. Pada bagian rimpang, ekstrak etanol, etil asetat, dan heksan rimpang renggak positif uji terpenoid, dan negatif uji steroid (Rachkeeree et al., 2020).

\section{Kesimpulan}

Berdasarkan penelitian yang telah dilakukan, rebusan dan ekstrak etanolik daun renggak (A. dealbatum) memiliki kandungan golongan senyawa metabolit sekunder. Rebusan dan ekstrak etanolik daun renggak mengandung senyawa flavonoid, alkaloid, dan tanin, namun hanya ekstrak etanolik daun renggak saja yang mengandung senyawa triterpenoid.

\section{Ucapan terima kasih}

Penulis mengucapkan terimakasih kepada Universitas Mataram yang telah mendanai penelitian ini.

\section{Referensi}

Badan Litbang Kesehatan (2011). Pedoman Umum Panen dan Pascapanen Tanaman Obat. Balai Besar Penelitian dan Pengembangan Tanaman Obat dan Obat Tradisional.

Bruneton, J. (1999). Pharmacognosy: Phytochemistry Medical Plants (2nd ed.). Intercept Ltd. 
Dalisay, J. A. G. P., Bangcaya, P. S., \& Naive, M. A. K. (2018). Taxonomic Studies and Ethnomedicinal uses of Zingiberaceae in the Mountain Ranges of Northern Antique , Philippines. Biological Forum-an International Journal, 10(2), 68-73.

Direktorat Pengawasan Obat Tradisional (2000). Parameter Standar Umum Ekstrak Tumbuhan Obat. Departemen Kesehatan Republik Indonesia.

Ergina, Nuryanti, S., \& Pursitasari, I. D. (2014). Uji Kualitatif Senyawa Metabolit Sekunder Pada Daun Palado (Agave angustifolia) yang Diekstraksi Dengan Pelarut Air dan Etanol. Jurnal Akademika Kimia, 3(3), 165-172.

Haseley, P., \& Oetjen, G.-W. (2018). FreezeDrying. Wiley-VCH.

Khisha, T., Karim, R., Chowdhury, S. R., \& Banoo, R. (2012). Ethnomedical Studies of Chakma Communities of Chittagong Hill Tracts, Bangladesh. Bangladesh Pharmaceutical Journal, 15(1), 59-67.

Malik, A., Edward, F., \& Waris, R. (2014). Skrining Fitokimia Dan Penetapan Kandungan Flavonoid Total Ekstrak Metanolik Herba Boroco (Celosia argentea L.). Jurnal Fitofarmaka Indonesia, 1(1), 1-5.

Marliana, S. D., Suryanti, V., \& Suyono. (2005). Skrining Fitokimia dan Analisis Kromatografi Lapis Tipis Komponen Kimia Buah Labu Siam (Sechium edule Jacq. Swartz.) dalam Ekstrak Etanol. Biofarmasi, 3(1), 26-31.

Meigaria, K. M., Mudianta, I. W., \& Martiningsih, N. W. (2016). Skrining Fitokimia dan Uji Aktivitas Antioksidan Ekstrak Aseton Daun Kelor ( Moringa oleifera ). Jurnal Wahana Matematika Dan Sains, 10(2), 1-11.

Muthmainnah, B. (2017). Skrining Fitokimia Senyawa Metabolit Sekunder Dari Ekstrak Etanol Buah Delima (Punica granatum L.)
Dengan Metode Uji Warna. Media Farmasi, 13(2), 23-28.

Noviyanti (2016). Pengaruh Kepolaran Pelarut Terhadap Aktivitas Antioksidan Ekstrak Etanol Daun Jambu Brazil Batu (Psidium guineense L .) Dengan Metode DPPH. Jurnal Farmako Bahari, 7(1), 29-35.

Nufus, N. H. (2020). Analisis Fitokimia dan Uji Potensi Ekstrak Buah Renggak (Amomum dealbatum) Sebagai Pestisida Nabati Terhadap Jamur Pyricularia oryzae Dan Bakteri Xanthomonas oryzae. Bioscientist : Jurnal Ilmiah Biologi, 8(1), 115-125.

Nugrahani, R., Andayani, Y., \& Hakim, A. (2016). Skrining Fitokimia dari Ekstrak Buah Bumcis (Phaseolus vulgaris) dalam Sediaan Serbuk. Jurnal Penelitian Pendidikan IPA (JPPIPA), 02(01).

Pancharoen, O., Prawat, U., \& Tuntiwachwuttikul, P. (2000). Phytochemistry of the Zingiberaceae. Studies in Natural Products Chemistry, 23, 797-865.

Pangestuty, A. (2016). Uji Aktivitas Antioksidan dan Penetapan Kadar Fenolik Total Fraksi Etil Asetat Ekstrak Etanol Buah Buni (Antidesma bunius L. (Spreng) dengan Metode 2,2-difenil-1-pikrilhidrazil (DPPH) dan Metode Folin-Ciocalteu. Universitas Sanata Darma Yogyakarta.

Prasasty, V. D., Haryani, B., Hutagalung, R. A., Mulyono, N., Yazid, F., Rosmalena, R., \& Sinaga, E. (2019). Evaluation of antioxidant and antidiabetic activities from red seaweed (Eucheuma cottonii). Systematic Reviews in Pharmacy, 10(1), 276-288.

https://doi.org/10.5530/srp.2019.1.44

Rachkeeree, A., Kantadoung, K., Puangpradub, R., \& Suksathan, R. (2020). Phytochemicals, antioxidants and antityrosinase analyses of selected ginger plants. Pharmacognosy Journal, 12(4), 872-883. 
https://doi.org/10.5530/pj.2020.12.125

Rahman, M. A. (2010). Indigenous knowledge of herbal medicines in Bangladesh. 3. Treatment of skin diseases by tribal communities of the hill tracts districts. Bangladesh Journal of Botany, 39(2), 169-177.

https://doi.org/10.3329/bjb.v39i2.7303

Sangi, M., Runtuwene, M. R. J., Simbala, H. E. I., \& Makang, V. M. A. (2008). Analisis Fitokimia Tumbuhan Obat Di Kabupaten Minahasa Utara. Chem. Prog., 1(1), 4753.

Sarangnga, Y., Suaib, S., \& Wijayanto, T. (2013). Karakterisasi Morfologi Tumbuhan Jahe-jahean (Zingiberaceae) Di Daerah Aliran Sungai Katangana Tiworo Selatan. Berkala Penelitian Agronomi, 2(2), 87-93.

Sholikhah, R. M. (2016). Identifikasi senyawa triterpenoid dari fraksi $\mathrm{N}$-Heksana ekstrak Rumput Bambu (Lophatherum gracile Brongn.) dengan metode UPLC-MS. Universitas Islam Negeri Maulana Malik Ibrahim.

Simaremare, E. S. (2014). Skrinig Fitokimia Ekstrak Etanol Daun Gatal (Laportea decumana (Roxb.) Wedd). Pharmacy, 11(01), 98-107.

Tushar, T., Basak, S., Sarma, G. C., \& Rangan, L. (2010). Ethnomedical uses of Zingiberaceous plants of Northeast India. Journal of Ethnopharmacology, 132(1), 286-296.

https://doi.org/10.1016/j.jep.2010.08.032

Widarta, I. W. R., \& Wiadnyani, A. A. I. S. (2019). Pengaruh Metode Pengeringan Terhadap Aktivitas Antioksidan Daun Alpukat. Jurnal Aplikasi Teknologi Pangan, 8(3), 80-85.

Widaryanto, E., \& Azizah, N. (2018). Perspektif Tanaman Obat Berkhasiat: Peluang, Budidaya, Pengolahan Hasil dan Pemanfaatan. UB Press.
Widiyati, E. (2006). Penentuan Adanya Senyawa Triterpenoid Dan Uji Aktivitas Biologis Pada Beberapa Spesies Tanaman Obat Tradisional Masyarakat Pedesaan Bengkulu. Jurnal Gradien, 2(1), 116-122.

Yulianingtyas, A., \& Kusmartono, B. (2016). Optimasi Volume Pelarut Dan Waktu Maserasi Pengambilan Flavonoid Daun Belimbing Wuluh (Averrhoa Bilimbi L.). Jurnal Teknik Kimia, 10(02), 58-64.

Yurleni (2018). Penggunaan Beberapa Metode Ekstraksi pada Rimpang Curcuma untuk Memperoleh Komponen Aktif Secara Kualitatif. Biospecies, 11(1), 48-56. 